\title{
ANÁLISE HISTOQUÍMICA FOLIAR DO AMENDOIM: GENÓTIPOS 'TATU' E SO-909 $\left({ }^{1}\right)$
}

\author{
RENATO FERRAZ DE ARRUDA VEIGA $\left({ }^{2,6}\right)$, GRACI MIRIAN CORSO $(3)$, \\ PAULO ROBERTO CURI $\left({ }^{4}\right)$ e JOÃo PAULO FEIJÃo TEIXEIRA $\left({ }^{5}\right)$
}

\begin{abstract}
RESUMO
Este trabalho teve por finalidade a análise histoquímica foliar de dois genótipos de amendoim (Arachis hypogaea L.), do tipo botânico Valéncia: SO-53 ('Tatu') e SO-909 (PI-259747), cuja literatura demonstra apresentarem respostas diferentes de resistência às principais moléstias fúngicas foliares do Brasil. Seçōes transversais das seguintes estruturas - pulvino, haste peciolar, raque, pulvínulo e folíolo - e seçôes paradermicas de folíolos coletados em dois anos agricolas consecutivos, foram analisadas quanto à presença de alcalóides, amido, calose, celulose pura, celulose com pectina, cera, cristais, cutina, lignina, mucilagem, óleo, resina, tanino e ureídeos (micrograma) por folíolo (grama). As diferenças qualitativas histoquímicas observadas nos diversos tecidos, como a freqüencia de tanino, alcalóide, pectina e bleo, supostamente, podem ser responsáveis pela resistencia ou suscetibilidade dos genótipos às moléstias fúngicas foliares. Para fins de caracterização, mostrou-se eficiente a avaliaçăo de pureza de celulose.
\end{abstract}

Termos de indexagãa: amenđoim, Arachis hypogaea L., análise histoquímica.

\section{ABSTRACT \\ LEAF HISTOCHEMICAL ANALYSES OF PEANUT: GENOTYPES ‘TATU’ AND SO-909}

Leaf histochemical analyses were made in two genotypes of Arachis hypogaea L.., of the Valencia group, which present different responses to some of the peanut foliar diseases. The analyses were performed on cross sections of the pulvini, petiole, rachis, pulvinulus and leaflets. The following constituents were observed: alkaloids, callose, cellulose with pectin, cristal, cutin, lignin, mucilage, oil, pure cellulose, resin, starch, tannin, wax and weight of ureides by leaflets. Some histochemical characteristics such the amount of tannin, alkaloids, pectin and oil can be produce different responses of peanut to foliar fungal diseases, and can be used in the characterization of peanut genotypes like the amount of pure cellulose and cellulose with pectin.

Index terms: peanut, Arachis hypogaea L., histochemical anałyses.

(1) Recebiđo para publicacão em 29 de janeiro e aceito em 15 de dezembro de 1992.

(2) Sistema de Introduçăo e Quarentena de Plantas, Instituto Agronômico (IAC), Caixa Postal 28, 13001-970 Campinas (SP).

(3) Departamento de Botânica, Universidade Estadual Paulista (UNESP), Caixa Postal 178, 13506-900 Rio Claro (SP).

(4) Serviço de Estatística, Faculdade de Medicina Veterinária e Zootecnia. Universidade Estadual Paulista (UNESP), $18610-970$ Botu catu (SP).

(5) Seção de Fitoquímica, IAC.

(6) Com bolsa de pesquisa do CNPq. 


\section{INTRODUÇÃO}

As variedades comerciais de amendoim mais difundidas no Estado de São Paulo, em especial o 'Tatu', apesar de sua grande capacidade produtiva, mostraram-se altamente suscetíveis às doenças da cultura (Moraes \& Godoy, 1984a, b). Isso, aliado a outros fatores, tem proporcionado um rendimento abaixo do seu potencial produtivo. Embora se utilizem medidas de controle às manchas foliares, o plantio de variedades resistentes possibilita a obtenção de custos mais baixos e maior rendimento (Moraes, 1981).

Escolheu-se o cultivar Tatu, pertencente à subespecie fastigiata, variedade fastigiata, tipo botânico Valência, oriundo de sementes coletadas por agricultores paulistas, e distribuído pelo IAC, desde a década de trinta, por ocupar a maior área de plantio em todo o território nacional. $O$ genótipo SO-909 (PI-259747), originário do Uruguai, foi escolhido por apresentar características opostas às do 'Tatu' com relaçāo à resistência às principais moléstias fúngicas foliares.

Alguns autores correlacionaram dados histoquímicos com resistência ou suscetibilidade das plantas (Rawlins, 1933; Aist, 1963; Galston \& Davies, 1972; Abdou et al., 1974; Buckup, 1981; Bailey, 1983), o que motivou a realização da análise histoquímica com um genótipo de características de resistência opostas às do 'Tatu', o SO-909, citado em alguns trabalhos nacionais de fitopatologia (Savy Filho \& Moraes, 1977; Moraes et al., 1978, 1983; Moraes \& Salgado, 1983; Moraes \& Savy Filho, 1983).

Além de visar ao possível conhecimento das causas da resistência ou suscetibilidade das folhas do germoplasma do tipo botânico Valência, relacionadas à histoquímica, procurou-se também abranger a caracterização dos genótipos do amendoim mediante a análise histoquímica.

\section{MATERIAL E METODOS}

O germoplasma utilizado neste trabalho foi obtido do Banco Ativo de Germoplasma de Amendoim do Instituto Agronômico (IAC), sendo os cultivares Tatu e SO-909, que apresentam caracte- rísticas opostas de resistência às moléstias fúngicas foliares (Quadro 1).

Do último ano de avaliaçōes do experimento de campo, coletou-se material para o preparo das exsicatas, que se encontram nos seguintes herbários: IAC, Instituto Agronômico de Campinas (SP); BOTU, UNESP-Botucatu (SP), e CTES, do Instituto de Botánica del Nordeste, em Corrientes (Argentina).

O Centro Experimental do Instituto Agronômico, em Campinas, foi escolhido como local para os ensaios de campo, os quais foram organizados em blocos ao acaso com seis blocos e dois tratamentos. Utilizaram-se três linhas de $2 \mathrm{~m}$ para cada germoplasma em cada bloco, no espaçamento de $0,70 \times 0,20 \mathrm{~m}$, realizando-se as observaçōes com material oriundo das plantas das linhas centrais, e permanecendo as outras como bordadura. O terreno foi previamente preparado e adubado, de acordo com Godoy et al. (1986), sem controle de pragas e moléstias, para evitar possível efeito dos defensivos químicos sobre a histoquímica da planta.

Efetuaram-se as análises histoquímicas em dois anos consecutivos, mediante cortes manuais realizados em material fresco, no mesmo dia da coleta, nas regiōes indicadas na figura 1. Para tanto, utilizaram-se os laboratórios do Sistema de Introdução e Quarentena de Plantas, da Seção de Fitoquímica do IAC, e do Departamento de Botânica da UNESP/Rio Claro. As folhas escolhidas foram as do quarto nó do caule, do ápice para a base, determinando-se para as análises apenas os foliolos superiores.

Alcalóides e amido foram reconhecidos pelo emprego da solução-de-lugol (Johansen, 1940).

Para evidenciar a presença de calose, colocaram-se seçōes longitudinais radiais de caules, pulvinos, haste peciolar e raque em solução aquosa de azul-de-anilina (Strasburger, 1913).

Para as observações de celulose pura e com pectina, trataram-se os cortes com uma gota da soluçāo-de-lugol e, a seguir, com uma gota de ácido sulfúrico a 70\% (Sass, 1958). Na presença da celulose pura, a coloração $e$ azul e, na de celulose com pectina, arroxeada. 
Observou-se a natureza dos cristais segundo a técnica de Strasburger (1913), tratando-se os cortes com ácido sulfúrico. Foram efetuados testes para cera, cutina e óleo, com solução-de-sudã IV (Johansen, 1940).

No teste para lignina, trataram-se os cortes com uma gota de solução de floroglucina a $2 \%$ em álcool etílico $95 \%$ e duas a três gotas de ácido clorídrico concentrado (Johansen, 1940).

Com relação às substâncias pécticas, submergiram-se os cortes em soluçáo aquosa de vermelho-de-rutênio (Jensen, 1962).

No teste de tanino, os cortes ficaram submersos em solução aquosa de cloreto de ferro III a $10 \%$, com uma pitada de carbonato de sódio (Jensen, 1962).
Analisou-se a mucilagem em cortes de material herborizado, sobre uma lâmina seca, adicionando-se uma gota de álcool absoluto; após colocar a lamínula, observaram-se as seções ao microscópio, irrigando-se as lâminas com água destilada e verificando o inchamento das células (Hawarth \& Warne, 1959).

Por intermédio da Seção de Fitoquímica, efetuou-se a análise de ureídeos (alantoína mais ácido alantóico). Os folíolos coletados do quarto $\mathrm{n} 6 \mathrm{em}$ plantas de casa de vegetação foram triturados em presença de solução de álcool etílico $80 \%(\mathrm{v} / \mathrm{v})$; filtrou-se, evaporou-se o álcool e dissolveu-se o resíduo em água destilada. Nesse extrato aquoso, determinou-se o teor de ureídeos por meio da reação colorimetrica com ferrocianeto de potássio e fenilidrazina com leitura em espectrofotômetro a $525 \mathrm{~nm}$ (Teixeira, 1984).

Quadro 1. Avaliação do grau de resistência às moléstias fúngicas foliares de amendoin $\left(^{1}\right)$, genótipos: 'Tatu' e SO-909

Moléstias

Cercospora arachidicola Hori

(mancha-castanha)

Cercosporidium personatum (Berk. \& Curt.)

Deighton

(pinta-preta)

Sphaceloma arachidis Bit. \& Jenk.

(verrugose)

$S$

(Moraes et al., 1978)

(Moraes et al., 1983)

Puccinia arachidis Speg.

(ferrugem)

(Moraes \& Salgado, 1983)

(Moraes \& Salgado, 1983)

$S$
Grau de suscetibilidade e referências

'Tatu' SO-909

(Savy Filho \& Moraes, 1977)

(Savy Filho \& Moraes, 1977)

R

$\mathbf{R}$

(Moraes \& Savy Filho, 1983)

(1) Tipo botanico Valéncia.

Obs: R: resistente; MR: moderadamente resistente, e S: suscetfvel. 


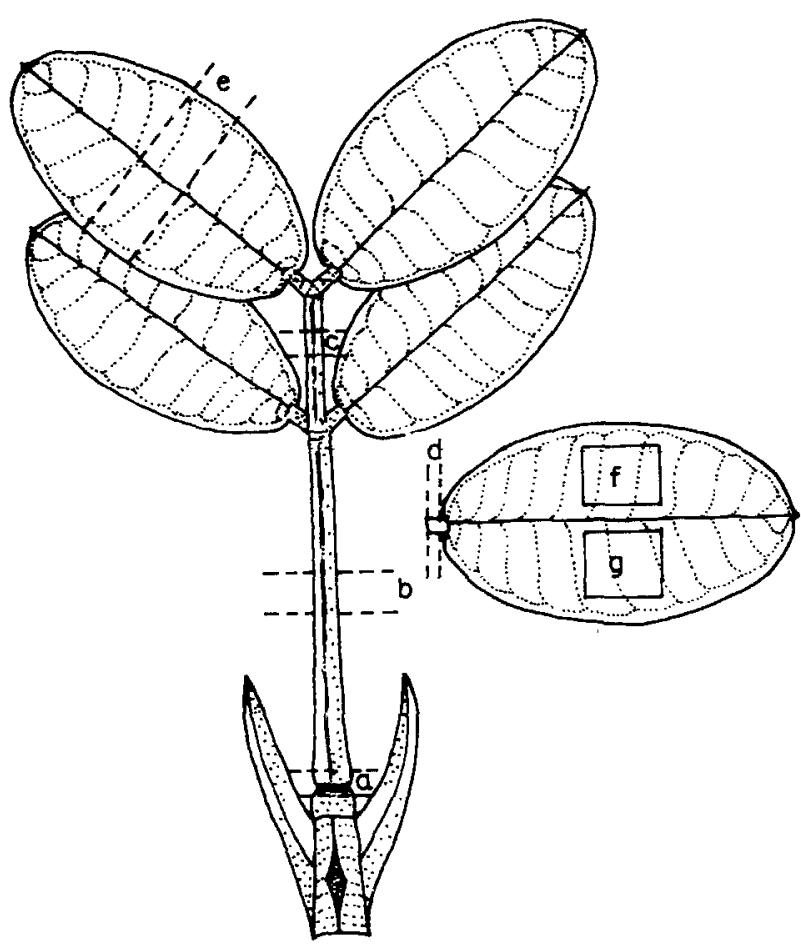

Figura 1. Regiōes da folha de Arachis hypogaea L. seccionadas para analises histoquímicas - a: seçăo transversal do pulvino; b: haste peciolar; c: raque; d: pulvínulo; e: folíolo; f: seçăo paradérmica adaxial e $\mathrm{g}$ : abaxial do folíolo.

A análise histoquímica teve variáveis qualitativas classificatórias, observadas em diferentes estruturas da mesma folha em dois anos, podendo as variáveis apresentar os seguintes valores:

- - = 0 (negativo para os dois anos);

+- ou $-+=1$ (positivo somente em um ano);

$++=2$ (positivo nos dois anos).

Utilizou-se a prova não paramétrica de Wilcoxon (Siegel, 1975) para a comparaçăo de duas amostras dependentes: amostra I ('Tatu') e amostra II SO-909.

\section{RESULTADOS}

Alcalóide - Nesse particular, existem diferenças entre os genótipos, apresentando o SO-909 maior número de células com precipitado (Quadro 2).
Quadro 2. Observações dè presença de alcalóide, prova não paramétrica de Wilcoxon, Arachis hypogaea L., 'Tatu' e SO-909, em 60 seções. 0 = Não observado nos dois anos; 1 = positivo somente em um ano; 2 = positivo nos dois anos. Avaliação efetuada em dois anos consecutivos

\begin{tabular}{lrrrrr}
\hline \multirow{2}{*}{ Freqüência } & & \multicolumn{3}{c}{ SO-909 (II) } & \\
\cline { 3 - 5 } & & 0 & 1 & 2 & Total \\
\hline & & & & & \\
\multirow{3}{*}{ 'Tatu' (I) } & 1 & 0 & 4 & 16 & 20 \\
& 2 & 0 & 0 & 11 & 11 \\
\hline & Total & 21 & 4 & 35 & 60 \\
\hline
\end{tabular}

Estatística calculada: $\mathrm{T}=0 ; \mathrm{p}<0,001$.

Existe diferença entre genótipos. A ocorrência de alcalóide é mais freqüente nas estruturas do SO-909.

Na seção transversal do pulvino, vê-se precipitado nas células da epiderme, parênquima do xilema, células basais dos pêlos e floema de ambos os genótipos, com maior freqüência no SO-909, onde foi observado também no parênquima fundamental e colênquima (Quadro 3).

No pecíolo, em seção transversal, verifica-se precipitado na maioria das células da epiderme do SO-909. Nos tricomas, constatou-se, nos dois materiais, a presença nas células basais e ausência na apical. $O$ teste foi positivo nas células hipodérmicas, no parênquima do xilema, floema e esclerênquima, com maior freqüência no SO-909; nas células da bainha, foi positivo somente para esse germoplasma (Quadro 3).

As observaçōes em seçāo transversal da raque mostraram precipitado mais freqüente nas células epidérmicas do SO-909, apresentando os tricomas a mesma composição daqueles do pecíolo.

O teste foi positivo nas células do colênquima e parênquima do SO-909 (Quadro 3). 

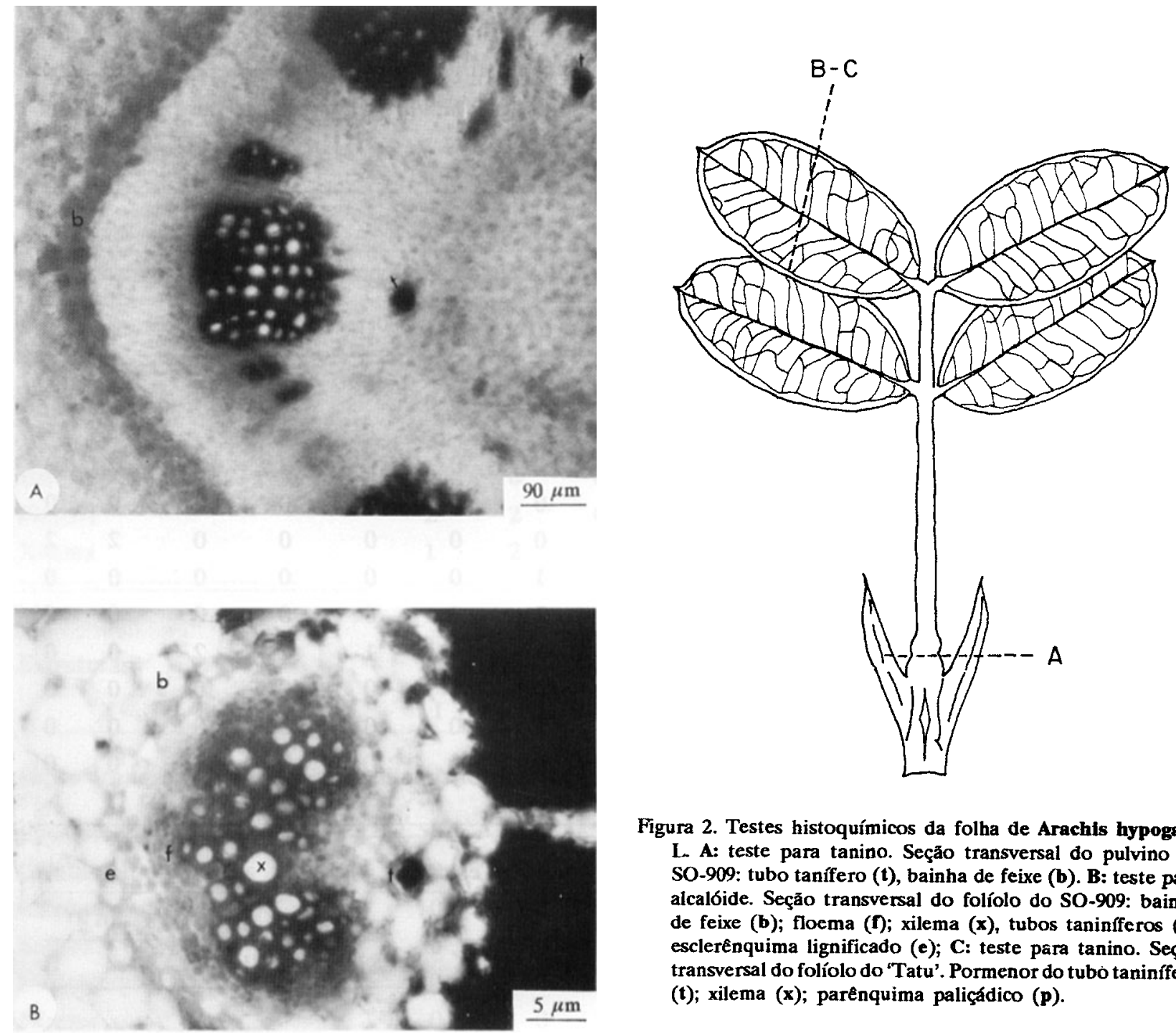

Figura 2. Testes histoquímicos da folha de Arachis hypogaea L. A: teste para tanino. Seção transversal do pulvino do SO-909: tubo tanífero (t), bainha de feixe (b). B: teste para alcalóide. Seção transversal do folíolo do SO-909: bainha de feixe (b); floema ( $(\mathbf{)}$; xilema ( $x$ ), tubos taninfferos ( $(t)$, esclerênquima lignificado (e); C: teste para tanino. Seçăo transversal do folíolo do 'Tatu'. Pormenor do tubo taninffero (t); xilema (x); parênquìma paliçádico (p).

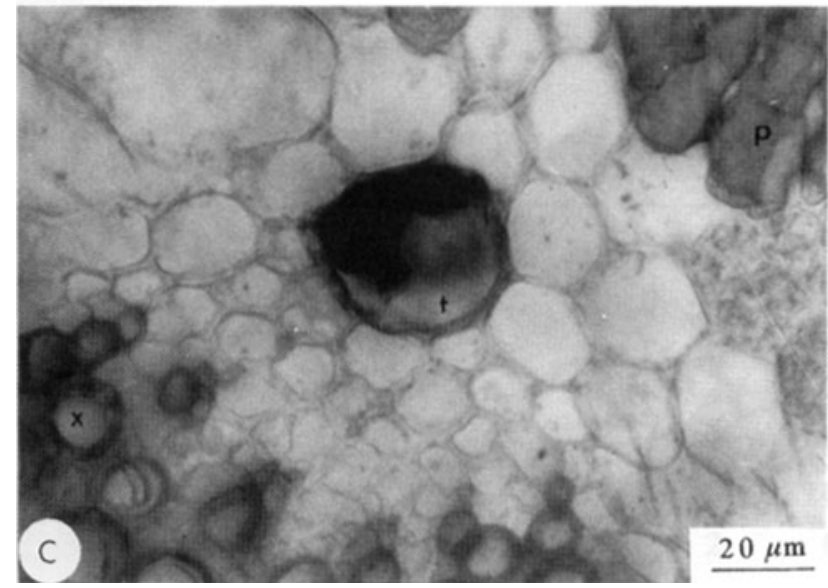

As observaçōes nos tricomas, nas células do parênquima do xilema e na epiderme em seção transversal do pulvínulo foram similares às da raque, sendo mais freqüente no floema do SO-909 (Quadro 3).

Em seções paradérmicas adaxial e abaxial dos folíolos, notou-se sua presença nas células epidérmicas dos dois genótipos, apresentando o SO-909 maior precipitado. $O$ teste foi positivo nas células estomáticas e subsidiárias do SO-909 e no 'Tatu', nas células subsidiárias em apenas um ano. Os tricomas são semelhantes aos do pecíolo (Quadro 3). 
Quadro 3. Testes histoquímicos em folhas de Arachis hypogaea L., 'Tatu' (I) e SO-909 (II). Observações realizadas por dois anos consecutivos de análises: alcalóide (al), amido (am), celulose pura (cp), cristal (cr), cutina (ct), lignina (lg), óleo (ól), pectina (pc) e tanino (tn)

Testes

Estruturas

\begin{tabular}{|c|c|c|c|c|c|c|c|c|c|}
\hline \multicolumn{2}{|c|}{ al } & \multicolumn{2}{|c|}{ am } & \multicolumn{2}{|c|}{$\mathrm{cp}$} & \multicolumn{2}{|c|}{ cr } & \multicolumn{2}{|c|}{ ct } \\
\hline I & II & I & II & I & II & I & II & I & II \\
\hline
\end{tabular}

Seção transversal do pulvino

Epiderme

Célula apical dos pêlos

Células basais dos pêlos

Clorênquima

Parênquima fundamental

Bainha

Colênquima

Floema

Xilema

$\begin{array}{llllllllll}1 & 2 & 2 & 2 & 0 & 0 & 2 & 2 & 2 & 2 \\ 0 & 0 & 0 & 0 & 0 & 0 & 0 & 0 & 0 & 0 \\ 2 & 2 & 0 & 0 & 0 & 0 & 0 & 0 & 2 & 2 \\ 0 & 0 & 2 & 1 & 0 & 0 & 0 & 0 & 0 & 0 \\ 0 & 2 & 2 & 2 & 0 & 0 & 0 & 0 & 0 & 0 \\ 0 & 0 & 2 & 2 & 0 & 1 & 2 & 2 & 0 & 0 \\ 0 & 2 & 0 & 0 & 0 & 0 & 0 & 0 & 0 & 0 \\ 2 & 2 & 1 & 1 & 0 & 0 & 0 & 0 & 0 & 0 \\ 1 & 2 & 1 & 0 & 0 & 0 & 0 & 0 & 0 & 0\end{array}$

Testes

Estruturas

\begin{tabular}{|c|c|c|c|c|c|c|c|}
\hline \multicolumn{2}{|c|}{ lg } & \multicolumn{2}{|c|}{ ól } & \multicolumn{2}{|c|}{ pc } & \multicolumn{2}{|c|}{ tn } \\
\hline I & II & I & II & I & II & I & II \\
\hline
\end{tabular}

Seção transversal do pulvino

\begin{tabular}{|c|c|c|c|c|c|c|c|}
\hline Epiderme & $\mathbf{0}$ & 0 & 2 & 2 & 2 & 2 & 1 \\
\hline Célula apical dos pêlos & $\mathbf{0}$ & 0 & $\mathbf{0}$ & 0 & 1 & 2 & $\mathbf{0}$ \\
\hline Células basais dos pêlos & 0 & 0 & $\mathbf{0}$ & 1 & 0 & 0 & 2 \\
\hline Clorênquima & 0 & 0 & 0 & 0 & 2 & 2 & 2 \\
\hline Parênquima fundamental & 0 & 0 & 2 & 2 & 2 & 2 & 2 \\
\hline Bainha & 0 & 0 & 0 & 0 & 2 & 1 & 0 \\
\hline Colênquima & 0 & 0 & $\mathbf{0}$ & 0 & 2 & 2 & 0 \\
\hline Floema & 0 & 0 & 2 & 2 & 1 & 2 & $\mathbf{0}$ \\
\hline Xilema & 2 & 2 & 2 & 2 & 0 & 0 & 0 \\
\hline
\end{tabular}


Quadro 3. Continuação

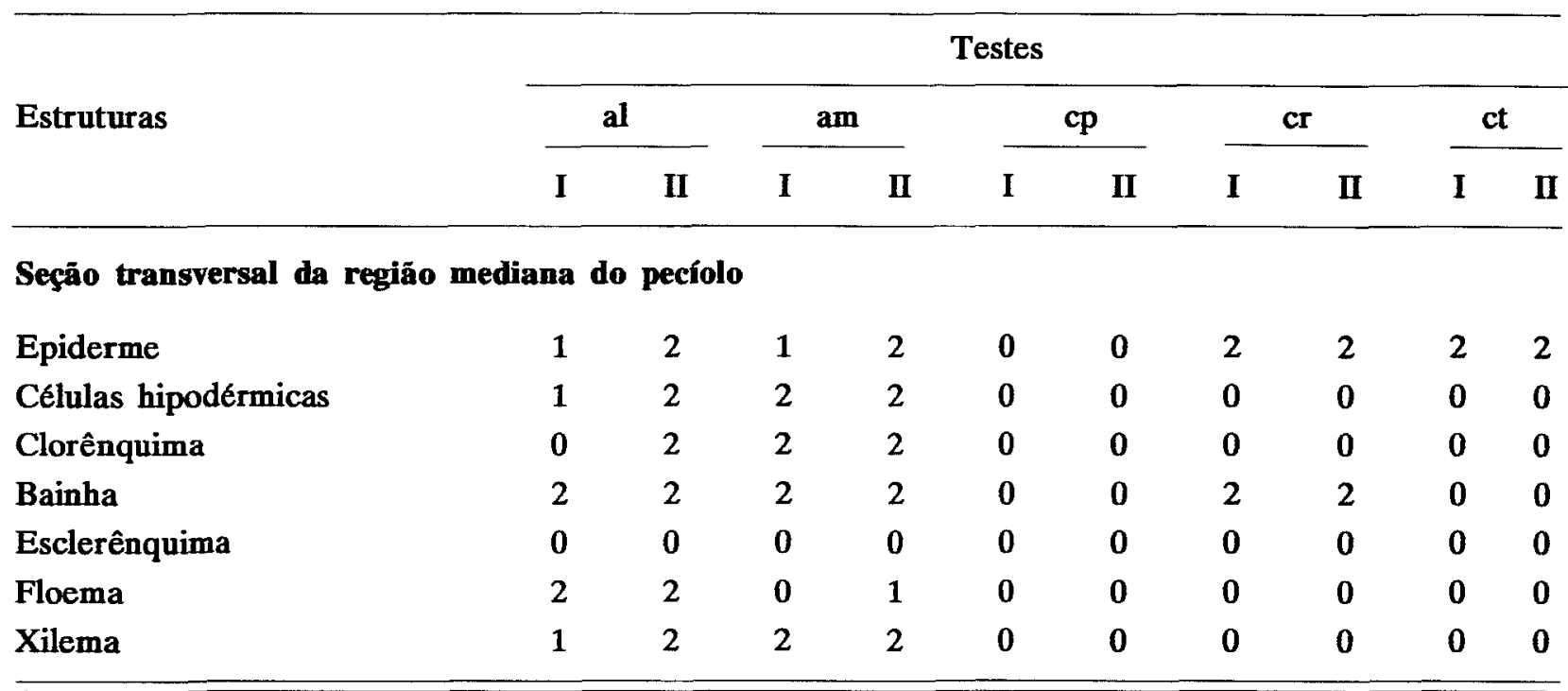

\section{Testes}

Estruturas

\begin{tabular}{|c|c|c|c|c|c|c|c|}
\hline \multicolumn{2}{|c|}{ lg } & \multicolumn{2}{|c|}{ ól } & \multicolumn{2}{|c|}{ pc } & \multicolumn{2}{|c|}{ tn } \\
\hline I & II & I & II & I & II & I & II \\
\hline
\end{tabular}

Seção transversal da região mediana do pecíolo

\section{Epiderme}

Células hipodérmicas

Clorênquima

Bainha

Esclerênquima

Floema

Xilema

$\begin{array}{ll}0 & 0 \\ 0 & 0 \\ 0 & 0 \\ 0 & 0 \\ 2 & 2 \\ 0 & 0 \\ 2 & 2\end{array}$

$2 \quad 2$

\section{2}

2

2

2

$0 \quad 0$

1

21

22

00

2

0

1

2

2

22

2
0

2

$\begin{array}{lll}2 & 2 & 2 \\ 2 & 1 & 1\end{array}$

$\begin{array}{llll}0 & 1 & 0 & 0 \\ 1 & 2 & 0 & 0 \\ 0 & 0 & 1 & 1\end{array}$

\section{Testes}

Estruturas

\begin{tabular}{|c|c|c|c|c|c|c|c|c|c|}
\hline \multicolumn{2}{|c|}{ al } & \multicolumn{2}{|c|}{ am } & \multicolumn{2}{|c|}{ cp } & \multicolumn{2}{|c|}{ cr } & \multicolumn{2}{|c|}{ ct } \\
\hline I & II & I & II & I & II & I & II & I & II \\
\hline
\end{tabular}

\section{Seção paradérmica adaxial}

Células epidérmicas

Estômatos

Células subsidiárias

Célula apical dos pêlos

Células basais dos pêlos

$\begin{array}{cccccccccc}1 & 2 & 2 & 2 & 2 & 1 & 2 & 2 & 2 & 1 \\ 0 & 2 & 2 & 2 & 1 & 0 & 0 & 0 & 2 & 2 \\ 1 & 2 & 0 & 0 & 1 & 0 & 0 & 0 & 2 & 1 \\ 0 & 0 & 0 & 0 & 1 & 0 & 0 & 0 & 0 & 0 \\ 2 & 2 & 0 & 0 & 0 & 0 & 0 & 0 & 2 & 2 \\ & & & & & & & & & \\ \text { Continua }\end{array}$


Quadro 3. Continuação

\section{Testes}

Estruturas

\begin{tabular}{|c|c|c|c|c|c|}
\hline lg & & & & & tn \\
\hline II & I & II & I & II & II \\
\hline
\end{tabular}

Seção paradérmica adaxial

Células epidérmicas

Estômatos

Células subsidiárias

Célula apical dos pêlos

Células basais dos pêlos

\begin{tabular}{llllllll}
0 & 0 & 2 & 2 & 0 & 2 & 2 & 2 \\
0 & 0 & 2 & 2 & 1 & 2 & 0 & 1 \\
0 & 0 & 2 & 2 & 1 & 2 & 2 & 2 \\
0 & 0 & 0 & 0 & 2 & 2 & 1 & 1 \\
0 & 0 & 0 & 0 & 0 & 0 & 1 & 1 \\
\hline
\end{tabular}

Testes

\begin{tabular}{|c|c|c|c|c|c|c|c|c|c|c|}
\hline \multirow[t]{2}{*}{ Estruturas } & \multicolumn{2}{|c|}{ al } & \multicolumn{2}{|c|}{ am } & \multicolumn{2}{|c|}{ cp } & \multicolumn{2}{|c|}{ cr } & \multicolumn{2}{|c|}{ ct } \\
\hline & I & II & I & II & I & II & I & II & I & II \\
\hline
\end{tabular}

Seção paradérmica abaxial

Células epidérmicas

Estômatos

Células subsidiárias

Célula apical dos pêlos

Células basais dos pêlos

\begin{tabular}{llllllllll}
1 & 2 & 2 & 2 & 2 & 1 & 2 & 2 & 2 & 2 \\
0 & 2 & 2 & 2 & 2 & 0 & 0 & 0 & 2 & 2 \\
1 & 2 & 0 & 0 & 2 & 0 & 0 & 0 & 2 & 2 \\
0 & 0 & 0 & 0 & 1 & 1 & 0 & 0 & 0 & 0 \\
2 & 2 & 0 & 0 & 0 & 0 & 0 & 0 & 2 & 2 \\
\hline
\end{tabular}

Testes

Estruturas

\begin{tabular}{|c|c|c|c|c|c|c|c|}
\hline \multicolumn{2}{|c|}{ lg } & \multicolumn{2}{|c|}{ ól } & \multicolumn{2}{|c|}{$\mathbf{p c}$} & \multicolumn{2}{|c|}{ tn } \\
\hline I & II & I & II & I & II & I & II \\
\hline
\end{tabular}

\section{Seção paradérmica abaxial}

Células epidérmicas

Estômatos

Células subsidiárias

Célula apical dos pêlos

Células basais dos pêlos

$\begin{array}{llllllll}0 & 0 & 2 & 2 & 0 & 2 & 2 & 2 \\ 0 & 0 & 2 & 2 & 0 & 2 & 1 & 2 \\ 0 & 0 & 2 & 2 & 0 & 2 & 1 & 2 \\ 0 & 0 & 0 & 0 & 2 & 2 & 0 & 0 \\ 0 & 0 & 0 & 0 & 0 & 0 & 2 & 2\end{array}$


Quadro 3. Continuação

\begin{tabular}{|c|c|c|c|c|c|c|c|c|c|c|}
\hline \multirow{3}{*}{ Estruturas } & \multicolumn{10}{|c|}{ Testes } \\
\hline & \multicolumn{2}{|c|}{ al } & \multicolumn{2}{|c|}{ am } & \multicolumn{2}{|c|}{ cp } & \multicolumn{2}{|c|}{ cr } & \multicolumn{2}{|c|}{ ct } \\
\hline & $\mathbf{I}$ & II & $\mathbf{I}$ & II & I & II & $\mathbf{I}$ & II & $\mathbf{I}$ & II \\
\hline \multicolumn{11}{|c|}{ Seção transversal do folíolo } \\
\hline Cutícula, face adaxial & $\mathbf{0}$ & $\mathbf{0}$ & $\mathbf{0}$ & $\mathbf{0}$ & $\mathbf{0}$ & $\mathbf{0}$ & $\mathbf{0}$ & $\mathbf{0}$ & 2 & 2 \\
\hline Cutícula, face abaxial & $\mathbf{0}$ & $\mathbf{0}$ & 0 & $\mathbf{0}$ & $\mathbf{0}$ & $\mathbf{0}$ & 0 & 0 & 2 & 2 \\
\hline Epiderme, face adaxial & 1 & 2 & 2 & 2 & 2 & 1 & 2 & 2 & 2 & 2 \\
\hline Epiderme, face abaxial & 1 & 2 & 2 & 2 & 2 & 1 & 2 & 2 & 2 & 2 \\
\hline Estômatos & $\mathbf{0}$ & 2 & 2 & 2 & 2 & $\mathbf{0}$ & $\mathbf{0}$ & $\mathbf{0}$ & 2 & 2 \\
\hline Célula apical dos pêlos & $\mathbf{0}$ & $\mathbf{0}$ & $\mathbf{0}$ & $\mathbf{0}$ & $\mathbf{0}$ & $\mathbf{0}$ & 0 & 0 & $\mathbf{0}$ & $\mathbf{0}$ \\
\hline Células basais dos pêlos & 2 & 2 & 0 & $\mathbf{0}$ & $\mathbf{0}$ & $\mathbf{0}$ & $\mathbf{0}$ & 0 & 2 & 2 \\
\hline Bainha dos feixes & 1 & 1 & 2 & 2 & 2 & 0 & 2 & 2 & 0 & 0 \\
\hline Xilema & 1 & 1 & 2 & 2 & 2 & $\mathbf{0}$ & $\mathbf{0}$ & 0 & $\mathbf{0}$ & $\mathbf{0}$ \\
\hline Floema & 2 & 2 & $\mathbf{0}$ & 0 & 2 & $\mathbf{0}$ & 0 & $\mathbf{0}$ & 0 & $\mathbf{0}$ \\
\hline Esclerênquima & $\mathbf{0}$ & $\mathbf{0}$ & $\mathbf{0}$ & $\mathbf{0}$ & $\mathbf{0}$ & $\mathbf{0}$ & $\mathbf{0}$ & 0 & 0 & 0 \\
\hline Colênquima & $\mathbf{0}$ & $\mathbf{0}$ & 2 & 2 & 2 & $\mathbf{0}$ & $\mathbf{0}$ & $\mathbf{0}$ & $\mathbf{0}$ & $\mathbf{0}$ \\
\hline Parênquima paliçádico & $\mathbf{0}$ & $\mathbf{0}$ & 2 & 2 & 0 & $\mathbf{0}$ & $\mathbf{0}$ & $\mathbf{0}$ & $\mathbf{0}$ & $\mathbf{0}$ \\
\hline Parênquima esponjoso & $\mathbf{0}$ & 0 & 2 & 2 & 0 & 0 & 0 & 0 & $\mathbf{0}$ & $\mathbf{0}$ \\
\hline Parênquima fundamental & 1 & 2 & 2 & 2 & 2 & $\mathbf{0}$ & 0 & $\mathbf{0}$ & $\mathbf{0}$ & $\mathbf{0}$ \\
\hline
\end{tabular}

Testes

Estruturas

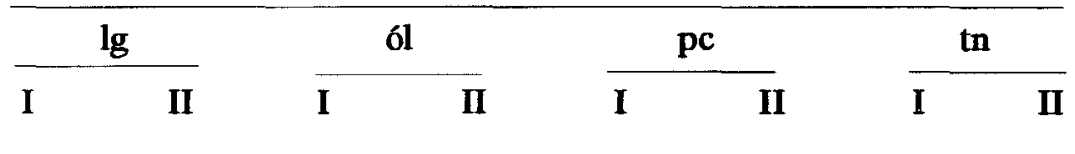

Seção transversal do folíolo

Cutícula, face adaxial

Cutícula, face abaxial

Epiderme, face adaxial

Epiderme, face abaxial

Estômatos

Célula apical dos pêlos

Células basais dos pêlos

Bainha dos feixes

Xilema

Floema

Esclerênquima

Colênquima

Parênquima paliçádico

Parênquima esponjoso

Parênquima fundamental

$\begin{array}{rrrrrrrr}0 & 0 & 0 & 0 & 2 & 2 & 0 & 0 \\ 0 & 0 & 0 & 0 & 2 & 2 & 0 & 0 \\ 0 & 0 & 2 & 2 & 2 & 2 & 2 & 2 \\ 0 & 0 & 2 & 2 & 2 & 2 & 2 & 2 \\ 0 & 0 & 2 & 2 & 2 & 2 & 0 & 0 \\ 0 & 0 & 0 & 0 & 2 & 2 & 0 & 0 \\ 0 & 0 & 0 & 0 & 0 & 0 & 0 & 0 \\ 0 & 0 & 2 & 2 & 2 & 2 & 1 & 2 \\ 2 & 2 & 2 & 2 & 0 & 0 & 1 & 2 \\ 0 & 0 & 1 & 1 & 0 & 0 & 0 & 0 \\ 2 & 2 & 0 & 0 & 2 & 2 & 0 & 0 \\ 0 & 0 & 2 & 2 & 2 & 2 & 0 & 0 \\ 0 & 0 & 0 & 0 & 0 & 0 & 0 & 0 \\ 0 & 0 & 0 & 1 & 2 & 2 & 0 & 0 \\ 0 & 0 & 2 & 2 & 0 & 0 & 0 & 0\end{array}$


Quadro 3. Continuação

\section{Testes}

Estruturas

\begin{tabular}{|c|c|c|c|c|c|c|c|c|c|}
\hline \multicolumn{2}{|c|}{ al } & \multicolumn{2}{|c|}{ am } & \multicolumn{2}{|c|}{ cp } & \multicolumn{2}{|c|}{ cr } & \multicolumn{2}{|c|}{ ct } \\
\hline I & II & I & II & I & II & I & II & I & II \\
\hline
\end{tabular}

\section{Seção transversal da raque}

Epiderme

Célula apical dos pêlos

Células basais dos pêlos

Células hipodérmicas

Clorênquima

Parênquima

Bainha

Esclerênquima

Floema

Xilema

Parênquima medular

$\begin{array}{llllllllll}1 & 2 & 2 & 2 & 0 & 0 & 2 & 2 & 2 & 2 \\ 0 & 0 & 0 & 0 & 0 & 0 & 0 & 0 & 0 & 0 \\ 2 & 2 & 0 & 0 & 0 & 0 & 0 & 0 & 2 & 2 \\ 1 & 2 & 0 & 0 & 2 & 0 & 0 & 0 & 0 & 0 \\ 0 & 2 & 2 & 2 & 2 & 0 & 0 & 0 & 0 & 0 \\ 0 & 2 & 0 & 0 & 2 & 0 & 0 & 0 & 0 & 0 \\ 0 & 0 & 2 & 2 & 2 & 0 & 2 & 2 & 0 & 0 \\ 0 & 0 & 0 & 0 & 0 & 0 & 0 & 0 & 0 & 0 \\ 2 & 2 & 0 & 0 & 2 & 0 & 0 & 0 & 0 & 0 \\ 1 & 1 & 2 & 2 & 0 & 0 & 0 & 0 & 0 & 0 \\ 0 & 0 & 0 & 1 & 2 & 0 & 0 & 0 & 0 & 0\end{array}$

Testes

Estruturas

\begin{tabular}{|c|c|c|c|}
\hline lg & ól & pc & tn \\
\hline II & II & II & $\bar{I}$ \\
\hline
\end{tabular}

Seção transversal da raque

Epiderme

Célula apical dos pêlos

Células basais dos pêlos

Células hipodérmicas

Clorênquima

Parênquima

Bainha

Esclerênquima

Floema

Xilema

Parênquima medular

$\begin{array}{llllllll}0 & 0 & 2 & 1 & 2 & 2 & 1 & 2 \\ 0 & 0 & 0 & 0 & 2 & 2 & 0 & 0 \\ 0 & 0 & 0 & 0 & 1 & 0 & 2 & 1 \\ 0 & 0 & 1 & 0 & 0 & 2 & 2 & 2 \\ 0 & 0 & 0 & 0 & 0 & 2 & 2 & 1 \\ 0 & 0 & 0 & 0 & 0 & 2 & 0 & 0 \\ 0 & 0 & 1 & 1 & 0 & 0 & 0 & 0 \\ 2 & 2 & 0 & 0 & 0 & 0 & 0 & 0 \\ 0 & 0 & 2 & 2 & 0 & 2 & 0 & 0 \\ 2 & 2 & 2 & 2 & 0 & 0 & 0 & 0 \\ 0 & 0 & 0 & 0 & 0 & 2 & 0 & 1\end{array}$


Quadro 3. Conclusão

\begin{tabular}{|c|c|c|c|c|c|c|c|c|c|c|}
\hline \multirow{3}{*}{ Estruturas } & \multicolumn{8}{|c|}{ Teste } & & \\
\hline & \multicolumn{2}{|c|}{ al } & \multicolumn{2}{|c|}{ am } & \multicolumn{2}{|c|}{$\mathrm{cp}$} & \multicolumn{2}{|c|}{ cr } & \multicolumn{2}{|c|}{ ct } \\
\hline & I & II & I & II & I & II & I & II & I & II \\
\hline
\end{tabular}

Secão transversal do pulvínulo

Epiderme

Célula apical dos pêlos

Células basais dos pêlos

Células hipodérmicas

Parênquima

Bainha

Floema

Xilema

$\begin{array}{llllllllll}\mathbf{1} & 2 & 2 & 2 & 0 & 0 & 2 & 2 & 2 & 2 \\ \mathbf{0} & 0 & 0 & 0 & 0 & 0 & 0 & 0 & 0 & 0 \\ 2 & 2 & 0 & 0 & 0 & 0 & 0 & 0 & 2 & 2 \\ 0 & 0 & 2 & 2 & 0 & 0 & 0 & 0 & 0 & 0 \\ 0 & 0 & 1 & 2 & 0 & 0 & 0 & 0 & 0 & 0 \\ 0 & 0 & 2 & 2 & 0 & 0 & 2 & 2 & 0 & 0 \\ 1 & 2 & 2 & 2 & 0 & 0 & 0 & 0 & 0 & 0 \\ 1 & 1 & 0 & 0 & 0 & 0 & 0 & 0 & 0 & 0\end{array}$

\begin{tabular}{|c|c|c|c|c|c|c|}
\hline \multicolumn{7}{|c|}{ Testes } \\
\hline & & & & & & tn \\
\hline I & $\overline{\text { II }}$ & I & II & I & II & I \\
\hline
\end{tabular}

\section{Seção transversal do pulvínulo}

Epiderme

Célula apical dos pêlos

Células basais dos pêlos

Células hipodérmicas

Parênquima

Bainha

Floema

Xilema

$\begin{array}{lll}0 & 0 & 2 \\ 0 & 0 & 1 \\ 0 & 0 & 0 \\ 0 & 0 & 2 \\ 0 & 0 & 2 \\ 0 & 0 & 0 \\ 0 & 0 & 2 \\ 2 & 2 & 2\end{array}$

2
0
0
2
2
0
2
2

2
2
0
2
2
1
0
0

$\begin{array}{lll}2 & 2 & 2 \\ 2 & 0 & 0 \\ 0 & 1 & 2 \\ 2 & 2 & 2 \\ 2 & 0 & 2 \\ 1 & 0 & 0 \\ 0 & 0 & 0 \\ 0 & 0 & 0\end{array}$

$0=$ ausência para os dois anos; 1 = alternância de presença e de ausência nos dois anos, e $2=$ presença para os dois anos. 
Na seção transversal do folíolo, além das estruturas citadas no item anterior, verificou-se a presença de precipitado em pequena quantidade na bainha dos feixes, parênquima do xilema, floema e parênquima fundamental; neste último, a freqüencia foi maior no SO-909 (Quadro 3 e Figura 2B).

Amido - Não se constatou diferença significativa entre genótipos - Quadro 4.

Na seção transversal do pulvino, foi positivo nas células das seguintes estruturas: epiderme, parênquima fundamental, bainha, floema, clorênquima e parênquima do xilema (Quadro 3).

O teste foi positivo nas células epidérmicas, hipoderme, clorênquima, bainha, parênquima do xilema e floema, na seção transversal do pecíolo (Quadro 3).

Na seção transversal da raque, observou-se amido nas células epidérmicas, clorênquima, bainha, parênquima do xilema e, em apenas um ano, no parênquima medular do SO-909 (Quadro 3).

Em seção transversal do pulvínulo, aparece o amido nas células epidérmicas, hipoderme, bainha, floema e parênquima do xilema (Quadro 3).

Nas seções paradérmicas adaxial e abaxial, foi positivo nas células epidérmicas, como nos estômatos (Quadro 3).

Na seçāo transversal do folíolo, foi positivo na bainha dos feixes, parênquima do xilema, colênquima, parênquima paliçádico, esponjoso e fundamental (Quadro 3).

Calose - Positivo no floema do caule, pulvino, haste peciolar e raque dos dois cultivares.

Celulose pura - Existe diferença entre os genótipos, sendo mais evidente no 'Tatu' (Quadro 5 e Figura 3 C-D).

Em seção transversal do pulvino do SO-909, constatou-se a presença de celulose pura em um ano nas células da bainha amilífera (Quadro 3).

Na raque do 'Tatu', em seção transversal, observou-se, em dois anos consecutivos, a presença de celulose pura na hipoderme, clorênquima, parênquima cortical, bainha amilífera, floema e parênquima medular (Quadro 3 e Figura 3E).

Na seção paradérmica adaxial do folíolo, notou-se a presença de celulose pura nas células epidérmicas do 'Tatu', nos dois anos consecutivos, e nos estômatos, células subsidiárias e célula apical dos pêlos, em apenas um ano. No SO-909, nas células epidérmicas em um ano (Quadro 3).

A presença na célula apical dos pêlos em seção paradérmica abaxial do folíolo foi constatada somente em um ano, nos dois genótipos. As células epidérmicas, estomáticas, subsidiárias e hipodérmicas do 'Tatu' apresentaram celulose pura nos dois anos (Quadro 3 e Figura $3 \mathrm{C}$ ).

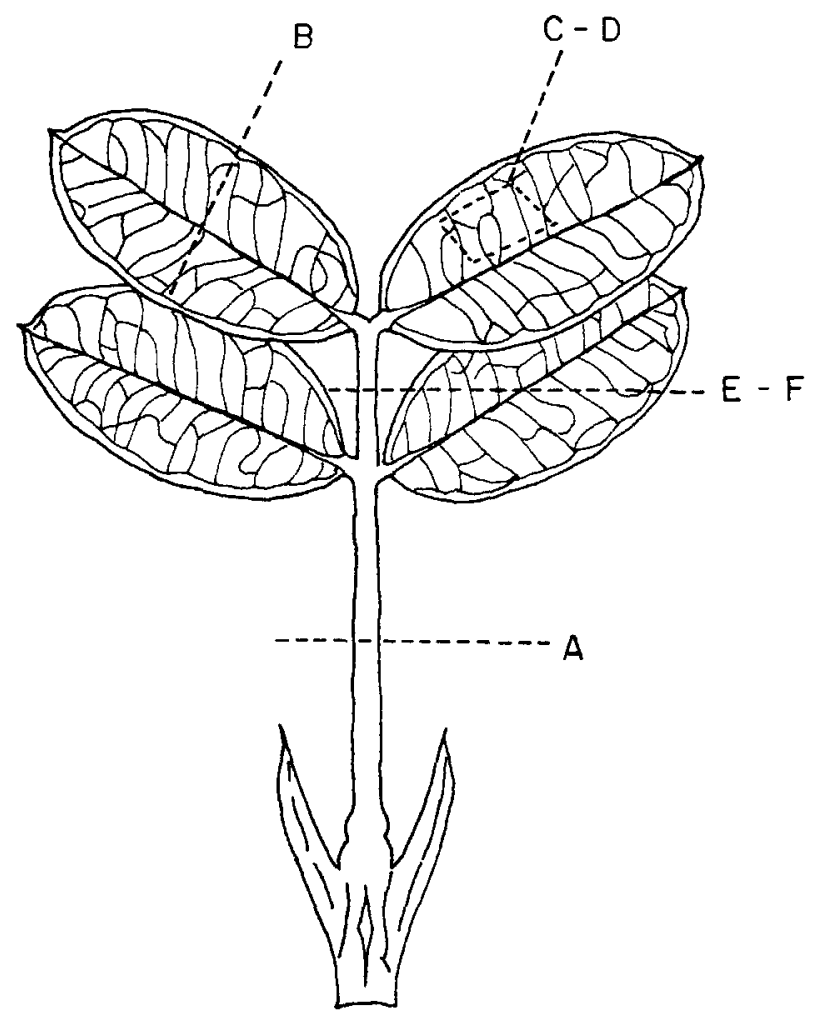

Figura 3. Testes histoquímicos das folhas de Arachis hypogaea L. A: teste para celulose com pectina. Seção transversal do peciolo do SO-909; pêlos: célula basal (b); célula apical (a); B: teste para celulose com pectina. Seção transversal do folíolo do SO-909; face adaxial: idioblasto mucilaginoso (m); célula epidérmica (e); C-D: teste para celulose pura. Seçăo paradérmica do folíolo - C: 'Tatu'; D: SO-909: epiderme (e), células hipodérmicas (h); E-F: teste para celulose pura. Seçāo transversal da raque - E: 'Tatu'; F: SO-909. 

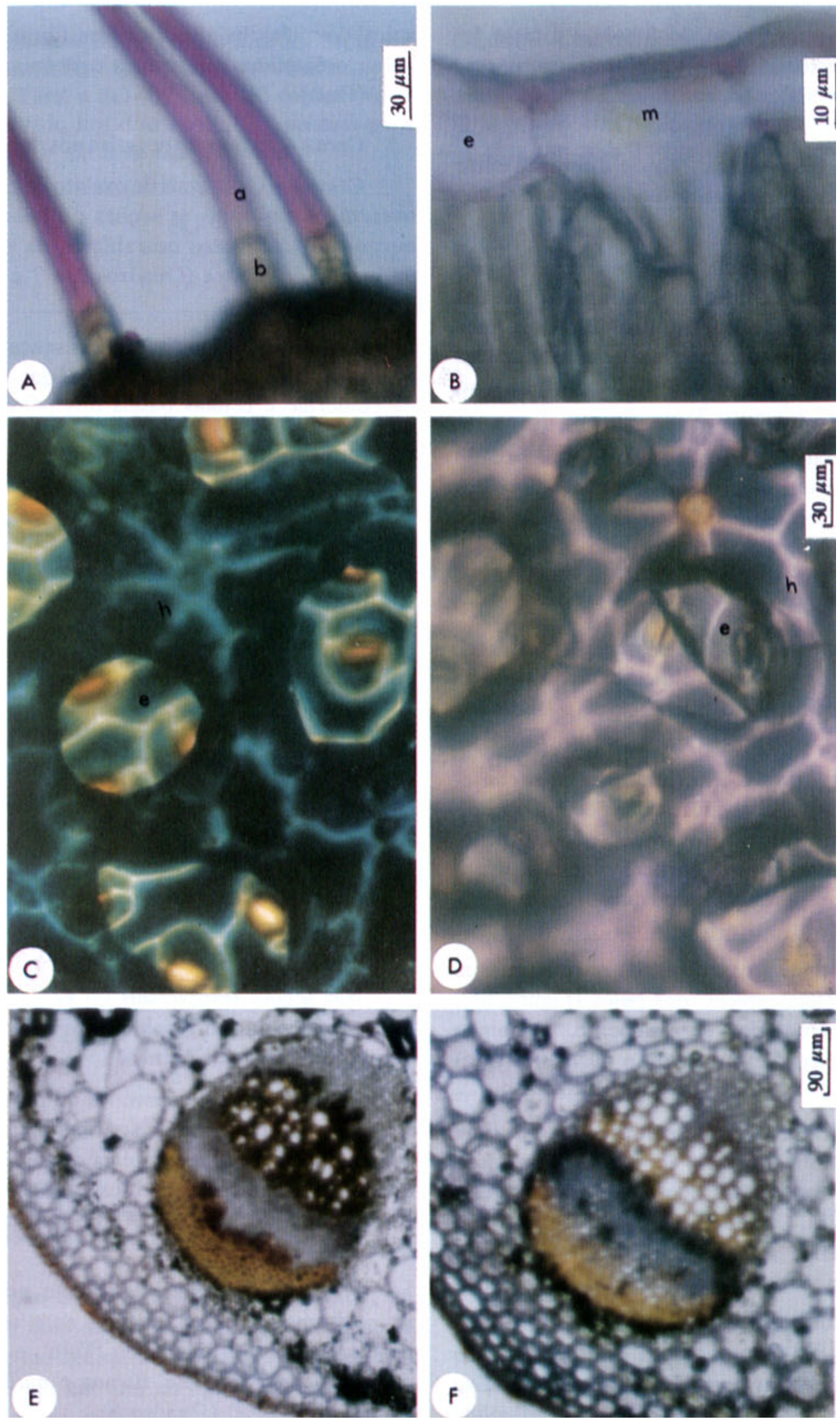
Na seção transversal do folíolo, o teste foi positivo nos estômatos, bainha dos feixes, parênquima do xilema, floema, colênquima e parênquima fundamental do 'Tatu' (Quadro 3).

Celulose com pectina - Existe diferença entre os dois cultivares, com maior evidência no SO-909 (Quadro 6).

Em ambos, o teste em seção transversal do pulvino foi positivo na epiderme, clorênquima, parênquima fundamental e colênquima. Em dois anos consecutivos, observou-se pectina nas células apicais dos pêlos e do floema do SO-909 e na bainha amilífera do 'Tatu' (Quadro 3).

As observaçōes em seção transversal do pecíolo foram positivas na epiderme, célula apical dos pêlos (Figura 3A), clorênquima e bainha nos dois genótipos. O SO-909 apresentou celulose com pectina na hipoderme e no floema, nos dois anos, e o 'Tatu', em um ano (Quadro 3).

$\mathrm{Na}$ raque do 'Tatu', em seçāo transversal, observou-se a presença de celulose com pectina nas células epidérmicas e nas células basais e apical dos pêlos.

Na raque do SO-909, em dois anos consecutivos, constatou-se celulose com pectina na epiderme, célula apical dos pêlos, hipoderme, clorênquima, parênquima cortical, bainha amilífera, floema e parênquima medular (Quadro $3 \mathrm{e}$ Figura 3F).

Nos dois cultivares, encontrou-se celulose com pectina na célula apical dos pêlos (Figura 3A), hipoderme, parênquima $\mathrm{e}$, raramente, na bainha amilífera, em seção transversal do pulvínulo (Quadro 3).

Em seções paradérmicas adaxial e abaxial do folíolo do SO-909, o teste foi positivo em todas as estruturas observadas, com exceção das células basais dos pêlos. $O$ 'Tatu' apresentou celulose com pectina na célula apical dos pêlos nos dois anos e, apenas em um ano, nas células estomáticas e subsidiárias, em seção paradérmica adaxial (Quadro 3 e Figura 3C).

Em seção transversal do folíolo, foi positivo na cutícula, epiderme (Figura 3B), estômatos, célula apical dos pêlos, bainha dos feixes, fibras gelatinosas do esclerênquima, colênquima e parênquima esponjoso (Quadro 3).

Cera - A análise foi negativa nos dois genótipos.

Cristais - Os cristais de oxalato de cálcio foram observados em todas as seções da folha, especialmente nos idioblastos cristalíferos da epiderme e na bainha dos feixes (Quadros 3 e 7 e Figura 4A e D).

Cutina - Verificou-se sua presença nas seçōes transversais do pulvino, pecíolo, raque e pulvínulo na epiderme e células basais dos pêlos (Quadros 3 e 8 ).

Nas seções paradérmica e transversal da face adaxial dos folíolos do 'Tatu', encontrou-se cutina nas células basais dos pêlos e nos estômatos e, na epiderme e nas células subsidiárias dos èstômatos, em dois anos consecutivos no 'Tatu' e em um ano no SO-909 (Quadro 3).

Lignina - Foi constatada no esclerênquima e xilema de todas as seçōes nos dois genótipos (Quadros 3 e 9).

Mucilagem - Em seçōes paradérmicas adaxial e abaxial e em seção transversal do folíolo, a presença de mucilagem foi positiva nos idioblastos mucilaginosos e nas células epidérmicas.

Na seção transversal do folíolo, também foi positiva na hipoderme, na bainha dos feixes e no parênquima paliçádico e esponjoso.

Nas seçōes transversais do pecíolo, pulvino, raque e pulvínulo, o resultado foi positivo na epiderme, hipoderme e bainha.

Óleo - Na seçāo transversal do pulvino, o teste foi positivo na epiderme, no parênquima fundamental, no floema e no parênquima do xilema nos dois genótipos. Somente foi verificada sua presença nas células basais nos pêlos do SO-909 em um ano (Quadros 3 e 10).

Na seção transversal do pecíolo, notou-se bleo na epiderme e bainha, em dois anos consecutivos no clorênquima e floema do 'Tatu', e em apenas um ano no clorênquima, floema e parênquima do xilema do SO-909 (Quadro 3). 
Quadro 4. Observações de presença de amido, prova não paramétrica de Wilcoxon, Arachis hypogaea L., 'Tatu' e SO-909, em 60 seçōes: $0=$ não observado nos dois anos; 1 = positivo para um ano; 2 = positivo nos dois anos

\begin{tabular}{lrrrrr}
\hline \multirow{2}{*}{ Freqüência } & & \multicolumn{3}{c}{ SO-909 (II) } & \\
\cline { 3 - 6 } & & 0 & 1 & 2 & Total \\
\hline & & & & & \\
'Tatu' (I) & 1 & 1 & 1 & 2 & 4 \\
& 2 & 0 & 1 & 28 & 29 \\
\hline & Total & 26 & 4 & 3 & 60 \\
\hline
\end{tabular}

Estatística calculada: $\mathrm{T}=7 ; \mathrm{p}>0,05$.

Não foi constatada diferença significativa entre os genótipos.

Quadro 5. Observaçōes de presença de celulose pura, prova não paramétrica de Wilcoxon, Arachis hypogaea L., 'Tatu' e SO-909, em 60 seçōes: $0=$ não observado nos dois anos; 1 = positivo para um ano; 2 = positivo nos dois anos

$$
\text { SO-909 (II) }
$$

Freqüência

Total

0

1

2

\begin{tabular}{rrrrrr} 
& 0 & 37 & 1 & 0 & 38 \\
'Tatu' (I) & 1 & 3 & 1 & 0 & 4 \\
& 2 & 14 & 4 & 0 & 18 \\
\hline & Total & 54 & 6 & 0 & 60 \\
\hline
\end{tabular}

Estatística calculada: $T=4,5 ; p<0,001$.

Existe diferença entre os genótipos, sendo a ocorrência de celulose pura mais freqüente no 'Tatu'.

Em seção transversal da raque do 'Tatu', foi positivo nos dois anos na epiderme, no floema $\mathrm{e}$ no xilema, e em apenas um na bainha e hipoderme. No SO-909, em um ano na epiderme e bainha e, em dois anos, no xilema e floema (Quadro 3).
Quadro 6. Observaçōes de presença de celulose com pectina, prova não paramétrica de Wilcoxon, Arachis hypogaea L., 'Tatu' e SO-909, em 60 seçōes: $0=$ não observado nos dois anos; 1 = positivo para um ano; 2 = positivo nos dois anos

\begin{tabular}{|c|c|c|c|c|c|}
\hline \multirow{2}{*}{ Freqüência } & & \multicolumn{3}{|c|}{ SO-909 (II) } & \multirow{2}{*}{ Total } \\
\hline & & 0 & 1 & 2 & \\
\hline & 0 & 16 & 1 & 9 & 26 \\
\hline \multirow[t]{3}{*}{ 'Tatu' (I) } & 1 & 1 & 1 & 6 & 8 \\
\hline & 2 & 0 & 1 & 25 & 26 \\
\hline & Total & 17 & 3 & 40 & 60 \\
\hline
\end{tabular}

Estatística calculada: $T=10 ; p<0,05$.

Existe diferença entre os genótipos. A observaçáo de celulose com pectina foi mais freqüente no SO-909.

Quadro 7. Observações de presença de cristais, prova não paramétrica de Wilcoxon, Arachis hypogaea L., 'Tatu' e SO-909, em 60 seçōes: $0=$ não observado nos dois anos; 1 = positivo para um ano; 2 = positivo nos dois anos

\begin{tabular}{|c|c|c|c|c|c|}
\hline \multirow{2}{*}{ Freqüência } & & \multicolumn{3}{|c|}{ SO-909 (II) } & \multirow{2}{*}{ Tot: } \\
\hline & & 0 & 1 & 2 & \\
\hline \multirow{4}{*}{ 'Tatu' (I) } & 0 & 47 & 0 & 0 & 47 \\
\hline & 1 & 0 & 0 & 0 & 0 \\
\hline & 2 & 0 & $\mathbf{0}$ & 13 & 13 \\
\hline & & 47 & $\mathbf{0}$ & 13 & 60 \\
\hline
\end{tabular}

Não foi efetuada a análise, pois houve concondância absoluta dos escores nos dois genótipos. Conclusão: para cristais, os genótipos são semelhantes.

Na seção transversal do pulvínulo, o teste foi positivo nos dois anos na epiderme, hipoderme e no floema e xilema, e em um ano na célula apical dos pêlos do 'Tatu' (Quadro 3). 
Quadro 8. Observações de presença de cutina, prova não paramétrica de Wilcoxon, Arachis hypogaea L., 'Tatu' e SO-909, em 60 seçōes: $0=$ não observado nos dois anos; 1 = positivo para um ano; $2=$ positivo nos dois anos.

\begin{tabular}{llll}
\hline \multirow{2}{*}{ Freqüência } & \multicolumn{3}{c}{ SO-909 (II) } \\
\cline { 2 - 4 } & 0 & 1 & 2 \\
\hline
\end{tabular}

\begin{tabular}{rrrrrr} 
& 0 & 39 & 0 & 0 & 39 \\
'Tatu' (I) & 1 & 0 & 0 & 0 & 0 \\
& 2 & 0 & 2 & 19 & 21 \\
\hline & Total & 39 & 2 & 19 & 60
\end{tabular}

Não foi efetuada a análise, pois nảo foi constatada diferença significativa entre ambos. Conclusão: para cutina, os genótipos são semelhantes.

Quadro 9. Observaçōes de presença de lignina, prova não paramétrica de Wilcoxon, Arachis hypogaea L., 'Tatu' e SO-909, em 60 seçōes: $0=$ não observado nos dois anos; 1 = positivo para um ano; 2 = positivo nos dois anos.

\begin{tabular}{llll} 
& \multicolumn{3}{c}{ SO-909 (II) } \\
\cline { 2 - 4 } Freqüência & 0 & 1 & 2 \\
\hline
\end{tabular}

\begin{tabular}{|c|c|c|c|c|c|}
\hline \multirow{3}{*}{ ‘Tatu' (I) } & 0 & 52 & 0 & 0 & 52 \\
\hline & 1 & 0 & 0 & $\mathbf{0}$ & 0 \\
\hline & 2 & 0 & 0 & 8 & 8 \\
\hline & tal & 52 & 0 & 8 & 60 \\
\hline
\end{tabular}

Não foi efetuada a análise, pois houve concordáncia absoluta dos escores nos dois genótipos. Conclusão: para lignina, ambos sâo semelhantes.

Nas seções paradérmicas adaxial e abaxial do folíolo, foi positivo na epiderme, estômatos e células subsidiárias (Quadro 3).
A seção transversal do folíolo confirmou os resultados das seçōes paradérmicas. Observou-se também, em dois anos, nos dois genótipos, a presença de óleo na bainha dos feixes, parênquima fundamental e colênquima, e em apenas um ano no floema. No SO-909, o óleo foi notado em um ano no parênquima esponjoso (Quadro 3).

Tanino - Na seção transversal do pulvino, os resultados foram positivos em dois anos consecutivos no clorênquima e parênquima fundamental $\mathrm{e}$, em um ano apenas, na epiderme dos dois genótipos. Foi positivo para o 'Tatu' nas células basais dos pêlos nos dois anos e, para o SO-909, em um ano; tambem foi observado na bainha deste em um ano (Quadros 3 e 11 e Figura 2A).

Em ambos, na seção transversal do peciolo, o resultado foi positivo na epiderme, na hipoderme e no clorênquima, em dois anos consecutivos, e apenas em um ano na bainha e no xilema (Quadro 3).

Na seção transversal da raque, o teste foi positivo na hipoderme dos dois genótipos, nos dois anos. No 'Tatu', foi positivo nas células basais dos pêlos e no clorênquima, nos dois anos, e em um ano na epiderme. No SO-909, foi positivo em dois anos na epiderme e em um ano nas células basais dos pêlos, no clorênquima e no parênquima medular (Quadro 3).

As observações na seção transversal do pulvínulo foram positivas na epiderme e na hipoderme. No 'Tatu', foi positivo em um ano nas células basais dos pêlos. No SO-909, nos dois anos, no parênquima e nas células basais dos pêlos (Quadro 3).

Nos dois genótipos, em seçāo paradérmica adaxial, o teste foi positivo nas células epidérmicas e subsidiárias, nos dois anos, e em um ano nas células apical e basais nos pêlos. No SO-909, o teste de tanino foi positivo para estômatos em um ano (Quadro 3).

Na seção paradérmica abaxial, observou-se, nos dois anos, tanino nas células epidérmicas e basais dos pêlos. No 'Tatu', foi positivo em um ano nos estômatos e nas células subsidiárias e, em dois anos, no SO-909 (Quadro 3). 

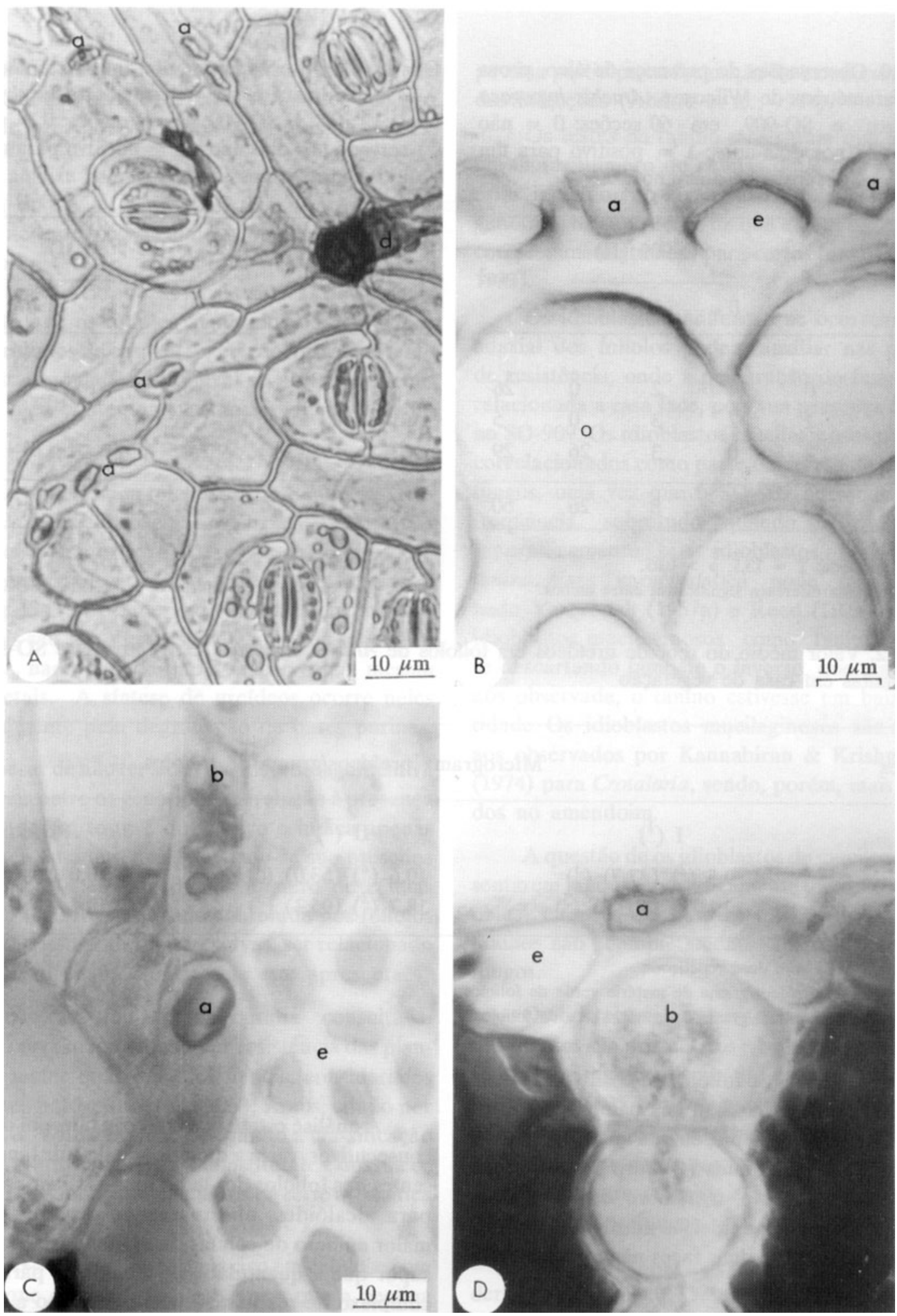

Figura 4. Pormenores de células com cristais em folhas de Arachis hypogaea L., 'Tatu'. A: epiderme da face abaxial do folíolo: ideoblasto cristalífero (a); base do pêlo cutinizada (d); B: nervura primária do folíolo: cristais (a), células epiđérmicas (e); colénquima (o); C: bainha dos feixes da raque (b): cristal (a), esclerênquima (e); D: extensão da bainha (b) dos feixes no lado adaxial do folíolo: cristal (a), célula epidérmica (e). 
Quadro 10. Observaçōes de presença de óleo, prova não paramétrica de Wilcoxon, Arachis hypogaea L., 'Tatu' e SO-909, em 60 seçōes: $0=$ não observado nos dois anos: 1 = positivo para um ano; 2 = positivo nos dois anos.

\section{Freqüência}

$$
\text { SO-909 (II) }
$$

Quadro 11. Observações de presença de tanino, prova não paramétrica de Wilcoxon, Arachis hypogaea L., 'Tatu' e SO-909, em 60 seções: $0=$ nāo observado nos dois anos; 1 = positivo para um ano; $2=$ positivo nos dois anos.

\begin{tabular}{rrrrrr}
\hline \multirow{3}{*}{ 'Tatu' (I) } & 0 & 24 & 2 & 0 & 26 \\
& 1 & 2 & 3 & 0 & 5 \\
& 2 & 0 & 3 & 26 & 29 \\
\hline & Total & 26 & 8 & 26 & 60 \\
\hline
\end{tabular}

Estatística calculada: $\mathbf{T}=13,5 ; \mathrm{p}>0,05$.

Não foi constatada diferença significativa entre ambos.

\begin{tabular}{rrrrrr} 
& 0 & 28 & 3 & 1 & 32 \\
'Tatu' (I) & 1 & 0 & 5 & 6 & 11 \\
& 2 & 0 & 3 & 14 & 17 \\
\hline & Total & 28 & 11 & 21 & 60 \\
\hline
\end{tabular}

Estatística calculada: $\mathrm{T}=19,5 ; \mathrm{p}>0,05$.

Houve uma tendéncia de diferença, com 'Tatu' SO-909.

Quadro 12. Valor médio do teor de ureídeos em folíolos de Arachis hypogaea L., 'Tatu' (I) e SO-909 (II), em plantas em casa de vegetação

\section{I $\left({ }^{1}\right)$}

Tatu

SO 909

$9,5\left(^{2}\right)(47,7)\left({ }^{3}\right)$
$20,3\left(\left(^{2}\right)(103,3)()^{3}\right)$

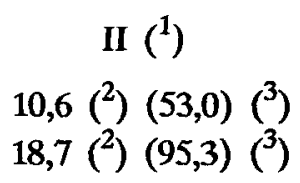$$
\text { II }\left({ }^{1}\right)
$$$$
10,6\left(^{2}\right)(53,0)\left({ }^{3}\right)
$$$$
18,7\left({ }^{2}\right)(95,3)\left({ }^{3}\right)
$$

Média

$10,0\left(^{2}\right)(50,4)\left({ }^{3}\right)$ $19,5\left({ }^{2}\right)(99,3)\left({ }^{3}\right)$

(1) Análise efetuada com duas repetiçōes;

(2) Micrograma de ureídeos/grama de matéria verde de folíolos;

(3) Micrograma de ureídeos/grama de matéria seca de folíolos.

Na seção transversal do folíolo, foi positivo nas duas faces da epiderme. No 'Tatu', na bainha dos feixes e no parênquima do xilema, em um ano (Figura 2C), e no SO-909 em dois anos (Quadro 3). Em seção paradérmica do folíolo, o número de ideoblastos taníferos foi maior na epiderme adaxial do SO-909, enquanto no 'Tatu' as duas faces não apresentaram diferença significativa.

Ureídeos - O valor médio de micrograma de ureídeos por grama de matéria seca de folíolos foi maior no SO-909 $(99,3 \mu \mathrm{g})$ do que no 'Tatu' (50,4 $\mu \mathrm{g})$ - Quadro 12.

\section{DISCUSSÃO}

A análise estatística mostrou que, em dois anos consecutivos, varia a quantidade de substâncias presentes nos folíolos dos genótipos avaliados. No teste para alcalóides, observaram-se precipitaçōes em maior número de células do SO-909. Isso possibilita supor que a quantidade de alcalóides participa do complexo de resistência desse genótipo a determinadas moléstias fúngicas foliares. Segundo Casamada (1977), porém, os alcalóides somente podem ser determinados com precisão quando se trata de substâncias em estado de pureza. Antes de tudo, as 
soluçōes devem estar livres de albuminóides, que dão resultados positivos com vários dos reativos gerais de precipitação e coloração dos alcalóides.

A análise foliar, efetuada na Seção de Fitoquímica do IAC, não confirmou os resultados obtidos no teste para alcalóides. Seguindo o método de Teixeira (1984), encontraram-se ureídeos que podem ter mascarado as observações. Levando-se em conta que os folíolos analisados para ureídeos foram oriundos de casa de vegetação, provavelmente com baixa nodulação pelo nível de ureídeos encontrados, fica patente sua maior quantidade no SO-909.

Não se verificam relatos de ureídeos como responsáveis por resistência às moléstias. Seu uso medicinal tem sido para assepsia e regeneração de tecidos animais lesados por ferimentos (Jenkins \& Hartung, 1943). Considerando que as células animais e vegetais sāo semelhantes, na maioria de seus componentes, nada impede que a reaçāo seja a mesma dos vegetais. A síntese de ureídeos ocorre neles principalmente pela degradação de bases purinas.

Apesar de não ter sido considerada significativa a diferença entre os genótipos em relação à presença de óleo, pois o teste é qualitativo e indica apenas a presença ou a ausência, verificou-se sua presença em ambos. No entanto, maior número de células contendo óleo foi observado sobretudo nos folíolos do SO-909: isso pode, com reservas, ser relacionado ao complexo de resistência que este apresenta.

Encontram-se, na bibliografia consultada, citaçōes correlacionando maior resistência das plantas com maior quantidade de fenóis, considerados tóxicos aos patógenos (Aist, 1963; Kraus, citado por Heitfuss \& Williams, 1976). Segundo a classificação moderna dos principais constituintes dos óleos essenciais, os fenóis são incluídos na série aromática (Casamada, 1977).

O SO-909 revelou-se mais rico em celulose com pectina que o 'Tatu'. Isso faz supor que a pectina tenha participado no complexo de resistência, fortalecendo a obstrução de penetração direta pela epiderme, entre as células, ou mesmo numa reação da planta ao desenvolvimento do fungo quando a pectina participa na formação de barreiras em torno das infecçōes (Abdou et al., 1974).

Os testes de tanino mostraram que ele existe em maior número de células do SO-909, podendo estar incluído no complexo de resistência desse genótipo: há suposiçōes de que alguns taninos sejam completamente tóxicos para certos fungos (Rawlins, 1933).

Os idioblastos taníferos que ocorrem na face adaxial dos folíolos podem auxiliar nas pesquisas de resistência, onde a penetração do fungo estiver relacionada a essa face, pois sua presença foi maior no SO-909. Os idioblastos mucilaginosos podem ser correlacionados como parte da defesa da planta aos fungos, uma vez que o SO-909 apresentou maior freqüência, sobretudo quando se observa que esporadicamente tais idioblastos podem conter tanino. Essa característica pode ter condicionado Yarbrough (1957a) e Reed (1924) a citar os idioblastos mucilaginosos como taniníferos, não se descartando também o inverso, que, na fase por nós observada, o tanino estivesse em baixa quantidade. Os idioblastos mucilaginosos são similares aos observados por Kannabiran \& Krishnamurthy (1974) para Crotalaria, sendo, porém, mais compridos no amendoim.

A questão de os idioblastos de mucilagem apresentarem tanino esporadicamente torna-se relevante pelas citações de Rawlins (1933), de que alguns taninos são completamente tóxicos para certos fungos.

Os cristais de oxalato de cálcio encontrados nos folíolos são prismáticos e isolados ou em grupos. Cristais prismáticos também foram observados por Yarbrough (1957b). Metcalfe \& Chalk (1950) citam para Arachis cristais em forma de bastão (estilóides). Nāo se encontrou, nos trabalhos consultados, correlação entre os cristais e a resistência ou suscetibilidade aos fungos.

Os dados obtidos permitem supor que a moderada resistência a Cercospora arachidicola (mancha-castanha), na fase de colonização do fungo para o SO-909, e a alta suscetibilidade do 'Tatu' (Savy Filho \& Moraes, 1977; Moraes, 1981; Moraes \& Salgado, 1983) devem-se à maior freqüência de tanino, 
pectina e, possivelmente, de alcalóides e óleo encontrada neste genótipo.

Sendo o SO-909 considerado altamente resistente e o 'Tatu', altamente suscetível, durante a colonização de Cercosporidium personatum (pinta-preta) (Savy Filho \& Moraes, 1977; Moraes, 1981; Moraes \& Salgado, 1983), supõe-se que, nessa fase, a resistência se deva à maior freqüência de tanino, pectina e, possivelmente, de óleo e alcalóides do 'SO-909'.

De acordo com os mecanismos de resistência citados para Puccinia arachidis (ferrugem) (Moraes et al., 1978; Subrahmanian et al., 1980; Moraes \& Savy Filho, 1983; Moraes et al., 1983; Subrahmanian \& McDonald, 1983), pode-se supor que a maior freqüência de tanino, pectina e, possivelmente, alcalóides e óleo do SO-909, participe do processo de resistência.

A possível interação entre a maior intensidade do ataque do inseto denominado tripes-do-amendoim (Eneothrips flavens Moulton) e a menor resistência ao fungo da verrugose (Sphaceloma arachidis) foi verificada por Rosseto et al. (1968). Isso se deve a que, durante o processo de infestação, $o$ inseto rompe os tecidos, facilitando a penetração do fungo. Todavia, não existem trabalhos que confirmem maior resistência ao inseto pelo SO-909. A maior freqüência de tanino do SO-909 poderia ser utilizada, como hipótese, como repelente aos insetos e, conseqüentemente, com menor penetração dos fungos nas folhas.

\section{CONCLUSŌES}

1. As folhas observadas apresentam composição histoquímica que possibilita distinguir os genótipos entre si.

2. Os principais componentes químicos foliares que os diferenciam sāo: a freqüência de pectina na epiderme foliar e a quantidade de ureídeos no folíolo.

3. A maior resistência a determinadas moléstias fúngicas foliares, mostrada pelo SO-909, está supostamente ligada a fatores histoquímicos, sobretudo pela maior freqüência de tanino e pectina.

\section{REFERÊNCIAS BIBLIOGRÁFICAS}

ABDOU, Y.A.M.; GREGORY, W.C. \& COOPER, W.E. Sources and nature of resistance to Cercospora arachidicola (Hori) and Cercosporidinm personatum (Berk. \& Curt.) Deighton in Arachis species. Peanut Science, Raleigh, 1:6-11, 1974.

AIST, J.R. Structural responses as resistance mechanism. In: BAILEY, J.A. \& DEVERALL, B.S. The dynamics of host defense. Sydney, Academic Press, 1963. p.33-70.

BAILEY, J.A. Biological perspectives of host-pathogen interactions. In: BAILEY, J.A. \& DEVERALL, B.S. The dynamics of host defense. Sydney, Academic Press, 1983. p.1-32.

BUCKUP, L. Botânica. 3.ed. Porto Alegre, SAGRA, 1981. 146p.

CASAMADA, R.S.M. Tratado de farmacognosia. Barcelona, Editorial Científico-Médica, 1977. 1121p.

GALSTON, A.W. \& DAVIES, P.J. Reaçóes e ferimentos. In: FERRI, M.G. Mecanismos de controle no desenvolvimento vegetal. Săo Paulo, Edgard Blücher, 1972. p.139-151.

GODOY, IJ. de; RODRIGUES FILHO, F.S. de O. \& GERIN, M.A.N. Amendoim (Arachis hypogaea L.). In: INSTTTUTO AGRONOMICO (Campinas). Instruçōes agrícolas para o Estado de Säo Paulo. 3.ed. Campinas, 1986. p.23. (Boletim, 200)

HAWARTH, W.O. \& WARNE, L.G. Practical botany for the tropies. London, University of London, 1959. 238p.

HEITEFUSS, R. \& WILLIAMS, P.H., eds. Physiological plant pathology. In: ENCYCLOPEDIA of plant physiology. New York, Springer-Verlog, 1976. v.4.

JENKINS, G.L. \& HARTUNG, W.H. The chemistry of organic medicinal products. 2.ed. New York, John Wiley, 1943. 675p.

JENSEN, W.A. Botanical histochemistry: principle and practice. San Francisco, W.H. Freeman, 1962. 408p.

JOHANSEN, D.A. Plant microtecnique. New York, McGrawHill, 1940. 528p.

KANNABIRAN, B. \& KRISHNAMURTHY, K.H. Morphology of foliar epidermis and taxonomy of the genus Crotalaria. Phytomorphology, Delhi, 24(1/2):61-68, 1974.

METCALFE, C.R \& CHALK, L. Anatomy of the dicotyledons. Oxford, Clarendon Press, 1950. v.2.

MILLER, L Microtécnica e fotomicrografia. Piracicaba, Fscola Superior de Agricultura "Luiz de Queiroz", 1968. n.p. (Apostila de Curso.)

MORAES,S.A. de. Técnica de folhas estacadas para testar reaçöes de cultivares de amendoim (Arachis hypogaea L) aos fungos Cercospora arachidicola Hori e Cercospora personata (Berk \& Curt) Ell \& Everh. Piracicaba, 1981. 107p. Tese (Doutorado em Agronomia)-ESALQ-USP, 1981. 
MORAES, S.A. de \& GODOY, IJ. de. Reaçōes de 17 genótipos de Arachis hypogaea L. a Cercospora arachidicola Hori e Cercospora personata (B. \& C.) Ell. \& Ev. Summa Phytopathologica, Piracicaba, 10(1/2):62-63, 1984a.

MORAES, S.A. de \& GODOY, IJ. de. Diferentes níveis de resistência a Cercosporidium personatum em genótipos de Arachis hypogaea. Summa Phytopathologica, Piracicaba, 11(1/2):74$-86,1984 \mathrm{~b}$.

MORAES, S.A. de; GODOY, I.J. de \& GERIN, M.A.N. Avaliação da resistencia de Arachis hypogaen a Poccinia arachidis, Sphaceloma arachidis e Phoma arachidicola. Fitopatologia Brasileira, Brasfia, 8(3):499-506, 1983.

MORAES, S.A. de \& SALGADO, C.L. Reaçōes de seis cultivares de amendoim (Arachis hypogaea) a Cercospora arachidicola $e$ C. personata em folhas destacadas. Fitopatologia Brasileira, Brasilia, 8(2):291-303, 1983.

MORAES, S.A. de \& SAVY FILHO, A. Reaçðes de seis cultivares de amendoim (Arachis hypogaea L.) a Puccinia arachidis Speg. Summa Phytopathologica, Piracicaba, 9(1/2):140-153, 1983.

MORAES, S.A. de; SOAVE, J. \& SAVY FILHO, A. Reações de 10 variedades de amendoim (Arachis hypogaea $L$.) à verrugose (Sphaceloma arachidis Bit. \& Jenk.). Ecossistema, Espírito Santo do Pinhal, 3(3):43-46, 1978.

RAWLINS, T.E. Phytopathological and botanical research methods. New York, John Wiley, 1933. 156p.

REED, E.L. Anatomy, embryology and ecology of Arachis hypogaea. Botanical Gazette, Chicago, 78(3):289-310, 1924.

ROSSETO, CJ.; RIBEIRO, I.J.A.; POMPEU, A.S. \& IGUE, T. Interaçăo entre o tripes, a verrugose e variedades do amendoinzeiro. In: REUNIÃO ANUAL DA SOCIEDADE BRASILEIRA PARA O PROGRESSO DA CIÊNCIA, 20., São Paulo, 1968. Ciência e Cultura, São Paulo, 20(2):255, 1968. Resumo.
SASS, J.E. Botanical microtechnique. 3.ed. Ames, Iowa State University Press, 1958. 228p.

SAVY FILHO, A. \& MORAES, S.A. de. Observaçbes sobre a incidencia de cercosporiose em cultivares de amendoim (Arachis hypogaea L.). Revista de Agricultura, Piracicaba, S2(1):39-46, 1977.

SIEGEL, S. Estatística não paramétrica. Săo Paulo, McGraw Hill, 1975. $350 \mathrm{p}$.

STRASBURGUER, E. Das Botanische Praktikum. Jena, g. Fischer, 1913. 860p.

SUBRAHMANYAM, P. \& McDONALD, D. Rust disease of groundnut. Patancheru, ICRISAT, 1983. 15p. (Information bulletin, 13)

SUBRAHMANYAM, P.; MEHNA, V.K; NEVILL, D.J. \& McDONALD, D. Research on fungal diseases of groundnuts at ICRISAT. In: INTERNATIONAL WORKSHOP ON GROUNDNUTS, Patancheru, 1980. Proceedings. Patancheru, ICRISAT, 1980. p.193-198.

TEIXEIRA, J.P.S. Translocaçäo de compostos nitrogenados da planta para os frutos em desenvolvimento e acúmulo de substâncias de reșerva em grãos de soja (Glycine max $\left(L_{\text {r }}\right)$ Merrill) cv. Santa Rosa Campinas, 1984. 168p. Tese (Mestrado em Biologia Vegetal) - Instituto de Biologia, UNICAMP, 1984.

YARBROUGH, J.A. Arachis hypogaea: the seedling, its epicotyl and foliar organs. American Journal of Botany, Baltimore, 44(1):19-30, 1957a.

YARBROUGH, J.A. Arachis hypogaea: the form and structure of the stem. American Journal of Botany, Baltimore, 44(1):31-36, $1957 \mathrm{~b}$. 